\title{
Text dynamics: Renewing challenges for semiotics of literature
}

\author{
Katalin Kroó \\ Department of Russian Language and Literature \\ Eötvös Loránd University \\ 1088, Múzeum krt 4/D, Budapest, Hungary \\ e-mail: krookatalin@freemail.hu
}

\author{
Peeter Torop \\ Department of Semiotics \\ University of Tartu \\ Jakobi 2, 51014 Tartu, Estonia \\ e-mail: peeter.torop@ut.ee
}

\begin{abstract}
The paper examines the problem of textual/cultural dynamics linked to the issue of semiotic literariness, to be further investigated by the authors in later papers on literary semiotics. This scientific project aims to get closer to reaching an adequate disciplinary identification for semiotics of literature and a relatively precise definition of the status of this field in relation to semiotics of culture. The first step for the project is to reveal the interrelationhip between text and culture using the notion of dynamics that can be reconstructed from a historical perspective through some essential components of Formalist and Structuralist theory (Tynyanov's 'function', Jakobson's 'dominant') and also works by Lotman (the 'text-culture' relationship) and Bakhtin ('dialogue'). The notions of inclusiveness/integration, distancing and hierarchization, leading to transformation, are interpreted in some detail in the context of these theories. On these grounds, three basic categories of the analysability of textual/cultural dynamics are set up with the indication of further aspects of the dynamic function: (1) mediation; (2) transposition; (3) temporality-spatiality. The suggested classification and the implied conceptual segmentation are expected to contribute to a synthesis between "Structuralist" and Peircean theoretical and methodological orientations in semiotic literary studies. This also reveals the need for a coexistence of approaches (a) moving from particular cultural fields (literary culture tradition) towards general semiotics of culture, and (b) returning from universal transfield concepts to literary
\end{abstract}


culture, including the historical traditions both in art (object-level) and its scientific interpretation (meta-level).

Keywords: cultural dynamics; semiotic literariness; Yurij Tynyanov; Roman Jakobson; Juri Lotman; Mikhail Bakhtin; mediation; transposition

\section{The preliminary - setting the task}

Thinking of text dynamics - which is called for by fresh cultural phenomena, serving as a constantly renewed challenge in the development of new conceptualizations and interpretations in literary semiotics (the semiotics of literature) - is impossible without going back to the basics. But what are these basics? What factors count as the most essential ones when treating the problem of text dynamics characterizing literature? And how can we define with at least some precision the scope and field of cultural semiotics in general and within it (or overlapping with it) the place of literary semiotics in particular? Even an approximate answer to these major questions might depend on how text dynamics is understood as related to literature and to the emergence of all of the cultural products in which semiotic literariness, ${ }^{1}$ i.e. the semiotic nature and features of the literary text can be revealed. In the long run, these inquiries are expected to enhance the opportunitiy of giving an adequate disciplinary identification of literary semiotics and find its status in relation to cultural semiotics. This might also provide an opportunity of grasping the semiotic literary nature of cultural texts emerging as a result of transmedial translations from pure literary texts par excellence (given in the verbal medium) or cultural products pertaining to other sign media. To set the research aims and perspectives of this paper with greater rigidity - in an age of intense orientation towards cultural transmedial transpositions and multimedial cultural productions, partly on the basis of, partly in the simultaneity of the coexistence with literary book culture (cf. Backe 2015; Mandell 2015; Alexander 2011) we should pose the question of the disciplinary identity of literary semiotics correctly, by defining the nature of semiotic literariness, to find it either in traditional book culture or in trans- or multimodal cultural texts.

For the concept of 'literariness' in Russian formalism, see Eichenbaum 2001: 1065-1066. Cf. Segal 2011: 83-85; Balcerzan 2016. By 'semiotic literariness' we mean literariness to be defined through its semiotic quality developing within the framework of semiotic systems. 


\section{Text and culture from the perspective of the set aim of the investigation}

As the suggested return to the "basics", the interpretation of some crucial aspects of the conceptualization of dynamics in the joint context of thought on the literary text, and on a more general cultural episteme, is required. The reason for this lies in the literary-historical fact that the theoretical roots from which the problem of dynamics emerged in this joint context, treating both the literary text and culture as a whole, can be traced back to Russian Formalism. Returning to Yurij Tynyanov's On Literary Evolution (1927) and Jakobson-Tynyanov's joint manifesto (1928), as well as to Jakobson's communication model and his definition of the poetic function, while not ignoring his concept of the dominant, might seem like a repetitive and superflous retaking of a well-trodden path. Proceeding along these lines has seemingly exhausted the research potentialities in certain directions, and has already supplied semiotic investigations with essential information and conclusions.

The most significant highlights in this respect occur in three interrelated fields relevant to the problem-posing of the present paper. The first concerns the formulation of a new conviction in Russian Formalism (with its further development within the framework of Czech Structuralism and the so-called "Russian Theory"; cf. Zenkin 2004), revealing itself in the shift from the qualification of the literary text by ignoring its true and many-faceted dynamic nature to the conceptualization of text as a dynamic whole (Hansen-Löve 2001). The second field is related to the explanation of the strong methodological impetus that the Russian Formalist and Czech Structuralist conceptualization of cultural dynamics (and its creative reworking by Juri Lotman and the Tartu-Moscow School of Semiotics) gave to the birth and development of the semiotics of culture, including the semiotics of literature (Salupere, Torop 2013; Kroó in print). The theoretical issue connected to the third field of clarification is closely linked to the first two, being a logical consequence of the Tynyanovian-Jakobsonian definition of dynamic culture, namely that the concepts of text and culture in certain respects become analogous. What is more, culture as an overall paradigm must, by necessity, include literary texts and these can be interpreted only within the much more general framework of cultural paradigms (cf. Lotman 1975, 1988; DeJean 1977; Portis Winner, Winner 1976). It is obvious then, that this realm of research tradition (the Russian Formalist School, Czech Structuralism, the Tartu-Moscow School of Semiotics and their permanent reinterpretations in ever newer critical metatexts cf. e. g., Danow 1986; Avtonomova 2009; Gherlone 2016) is a must in the further treatment of the problem of dynamics within literary and cultural semiotics. 
Our intention in this paper is to provide a reaccentuation of this particular critical heritage by going further in revealing the analogous nature of text and culture. It is essential to scrutinize this problem again in a historical critical context (from the point of view of the semiotics of literature and culture serving as a genetic context), by grasping the exact instances of the literary textual and overall cultural dynamics, in order to check if the textuality of the general cultural paradigm and the cultural nature of the literary text entirely coincide or show individual traits or features that can be mutually translated on the plane of theoretical metalanguage. To determine the status of the semiotics of literature within cultural semiotics we need to observe the extent of the validity of the analogy between the literary text and culture as text. If the analogy proves to work too well, then it will be impossible to define the literary text as a specific cultural construct with the trait of semiotic literariness. If the possibility of the identification of this trait is lost, literature cannot be recognized, and, what is equally important, this kind of semiotic literariness cannot be analysed and evaluated in a multimedial construct or transmedial translation/transposition. In this case we should note that there is no such scholarly episteme which can be called literary semiotics/the semiotics of literature.

\section{Reformulating the task in methodological terms - reversing the track}

Before turning to the study of the theoretical aspects through which the relationship between the concept of text and culture was developed in the context of the interpretation of their dynamic quality (or interpreting the implicit understanding of this relationship in theoretical research beginning with Russian Formalist thinking), in this section of our paper we identify a methodological strategy for our proposed investigation.

Roman Jakobson and Jurij Tynyanov's article (Jakobson, Tynjanov 1987[1928]), linking certain cultural series to the whole body of culture, did not ignore the importance of the separate treatment of the particular series interacting within culture. Taking literature as the major research object, the "system of systems" is meant to be "the correlation between the literary series and other historical series", which "has its own structural laws", without the investigation of which "the question of a specific choice of path, or at least of the dominant path of evolution" cannot be solved when there are "several, theoretically possible, evolutionary paths" (Jakobson, Tynjanov 1987[1928]: 30-31). Without the "disclosure of the immanent laws of the history of literature (and language)" it is impossible to define "the character of each specific change in literary (and linguistic) systems," - "it would be methodologically fatal to consider the correlation of systems without taking into account the immanent 
laws of each system." (Jakobson, Tynjanov 1987[1928]: 30-31). The immanent analysis of a specific series and the correlative investigation of the "isolationist" interpretations of the adjacent series to understand the "system of systems" (culture in the sense of the "series of series" as a complex correlation) constitute a basic premise accounting for the evolutionary dynamics of both, a specific branch of art as a series and culture as an overall system. The main issues in the understanding where this double perspective cannot be ignored concern the tempo and the variability of the evolution of a series within the cultural whole.

Tynyanov's idea had already appeared in his article "On literary evolution": "[...] the study of literary evolution is possible only in relation to literature as a system, interrelated with other systems and conditioned by them. Investigations must go from constructional function to literary function; from literary function to verbal function" (Tynjanov 1971[1927]: 77). By "verbal function", the idea of the interrelationship with everyday communication is implied, whereas the "constructional function" of the literary work is understood as "the interrelationship of each element with every other in a literary work and with the whole literary system" (Tynjanov 1971[1927]: 68). Lotman (2009: 133) would reformulate the principle of the inseparability of the immanent and correlative analyses in a more general context when relating this double methodological claim to culture as a whole:

The dynamics of culture can be represented as neither an isolated immanent process nor the passive sphere of external influences. Both these tendencies are realised in conditions of mutual tension from which they cannot be abstracted without the distortion of their very essence. Intersection with other cultural structures may be achieved in a variety of ways.

When we turn to evaluating Formalist theory and the resulting development of cultural semiotics, including the forms of its self-description, the main tendency which can be identified - even if evidently taking a reductionist view - is the movement from the immanent to the correlative context (cf. the shift from the interpretation of a particular cultural series - in our case, literature, which was the initial and major research object of Russian Formalist theory - to the conceptualization of a broader cultural domain). The shift was present not only in the third phase of Russian Formalism with its transfiguration into the spirit of Jakobson and Tynyanov's famous manifesto (Hansen-Löve 2001), but has appeared also in later proceedings in this domain. The strengthening of cultural semiotics as a discipline or a disciplinary field within semiotics ${ }^{2}$ also unambiguously demonstrates this direction.

2 On the dilemma of semiotics being a discipline, see Sonesson 2008; on the definition of cultural semiotics, see Torop 2015. 
The logic of this development is mirrored in one of the crucial attempts of the metatexts of culture to find universal concepts and operational tools through which the various branches of art (as Tynyanov would put it: cultural "series") can be understood and explained, as belonging to the more general category of culture. In this way, they can be interpreted with their explicit or implicit relatedness to one another through a scientific metalanguage which at the same time allows researchers to see all these cultural patterns as having a place within the framework of broader cultural contexts (taken to the extreme, within Culture as a whole). In this spirit, semiotics of culture has launched its internal project, interpreting cultural phenomena by bringing into being methodological and conceptual transfers from one cultural field, with its scholarly interpretation, to another. To this methodological logic belongs extending the scope of narratology into various cultural domains (e.g. visual culture, music, cf. Wolf 1999; Ryan 2001; Wolf, Bernhart 2006; Kress, Leeuwen 2006; Heinen, Sommer 2009) and to the cultural phenomena of intermediality/transmediality (e.g. Elleström 2016; Thon 2016; Bruhn 2016). Mythological decodings may also combine cultural products of various fields (Toporov 1978; Piatigorsky 1993; Freidenberg 1997; Lotman, Uspensky 1978; Meletinskij 2000) alongside narratological explanations and the interpretation of the function of symbols ${ }^{3}$ and tropes in general. The chronotopical system, discernible in all cultural texts where there exists narrativity, also offers the opportunity of applying a common approach in the interpretational processes. Last but not least, we can also take the text for such a universal category transcending a particular cultural field.

Accordingly, the analysability of culture in its various parts and manifestations calls for the conceptualization of text as an operational tool. Pyatigorskij (1996) stated in his "Notes from the 90 s on the semiotics of the 60s" that the notion of the text introduced in Lotman's Lectures on Structural Poetics as a fundamental notion of semiotics, played a crucial role, and at the same time, conveyed the notion of the "neutral" in relation to literature as the research object of semiotics. It was precisely the text which gave the opportunity to Lotman "to move from literature to culture as a

3 For Juri Lotman, "symbol serves as a condensed programme for the creative process. The subsequent development of a plot is merely the unfolding of a symbol's hidden possibilities. A symbol is a profound coding mechanism, a special kind of 'textual gene'. [...] A symbol always has something archaic about it. Every culture needs a body of texts which serves the function of archaism. Symbols cluster here thickly and with reason because the core group of symbols are indeed archaic and go back to pre-literate times when certain signs (which are as a rule elementary space-indicators) were the condensed mnemonic programmes for the texts and stories preserved in the community's oral memory. Symbols have preserved this ability to store up extremely long and important texts in condensed form” (Lotman 1990: 101, 103). 
universal object of semiotics" (our translation - K. K., P. T.; cf. Pyatigorskij 1996: 554). Pyatigorskij puts emphasis on the fact that, whereas literature is an "organic research object", culture proves to be a "metanotion, i.e. a term used for description (and selfdescription), which can be applied in any description whatsoever, including here the fact of the description of something as culture. (In the latter case culture ceases to be a metanotion.)" (Pyatigorskij 1996: 55). Pyatigorskij here discusses not simply the idea lying behind the definition formulated in the Theses (Lotman et al. 2013[1973]), according to which " $[\mathrm{t}]$ he fundamental concept of modern semiotics - the text - may be considered a connecting link [объединящим звеном] between general semiotic and special studies such as Slavistics" (Lotman et al. 2013[1973]: 57). He underlines that while literature represents an "organic research object" (belonging to semiotic realities), the notion of culture can also be interpreted as belonging to the level of metalanguage as an abstract notion. However, as stated in the Theses, "[s]cientific investigation is not only an instrument for the study of culture but is also part of its object" (Lotman et al. 2013 [1973]: 77). At the same time, the Theses explain that it is necessary to make a distinction between "the investigator of culture" and its "carrier" - for the investigator "the text appears as the carrier of integral function [иелостного значения]", while from the point of view of the other position "it is the carrier of integral meaning [целостной функизи]” (Lotman et al. 2013[1973]: 57-58). The example of the notion of text in this way demonstrates how the use of this universal concept serving as a "connecting link [объединяющим звеном]" between general semiotics and the studies of particular cultural fields (cf. 'series') may in fact be related to various phenomena (culture and metaculture) and also to various points of view in the interpretation (e.g. the researcher and the native consumer of culture).

The explicit programme of cultural investigation (with its implicit semiotic orientation) launched by the Formalist and Czech Structuralist theory and methodology can be considered successful in cultural semiotics, thanks to the further generalization of universal notions (text, narration, mythology, tropes, chronotope, etc.), on the basis of which appropriate analytical operational tools have been developed for studying a great variety of cultural phenomena within the framework of the general notion of culture. These universal categories (notions and terms) gave

4 Сf. “В лотмановских Лекииях огромную роль сыграло введение понятия «текст» как фундаментального понятия семиотики и, одновременно, как понятия нейтрального в отношении её объекта, литературь. Именно «текст» дал возможность Юрию Михайловичу перейти от литературы к культуре как универсальному объекту семиотики. Но литература - это органический объект, а культура - это метапонятие, термин описания (и само-описания), применимый, в приниипе, к любым описаниям, чего бы то ни было, включая сюда и факт описания чего-то как культуры. (В последнем случае культура перестает быть метапонятием)" (Pyatigorskij 1996: 55). 
flexibility to the metalanguage of cultural semiotics, heightening its capacity to serve in the many-faceted analysability of culture taken as a polyglot system, which at the same time sets cultural texts in a communicative space and renders different cultural phenomena comparable.

Remembering again Tynyanov and Jakobson's, as well as Lotman's, call for highlighting the significance of the so-called "immanent" analysis of the individual cultural "series" and culture as a whole, it is worth taking a fresh look at the condition of the contemporary semiotics of culture from this particular point of of "immanent" analysis. In this context, the notion 'immanent' by no means suggests that the research object (in our case literature) should be studied as a self-contained cultural entity. On the contrary, when Tynyanov (1971[1927]) stresses that literature is a complex system, and it is in this historical system that each literary work finds its place, ${ }^{5}$ this entails that the credo of immanent analysis implies the study of the complexity of how a literary element may belong to a literary system taken as a whole (for a detailed interpretation of the immanent approach, see Kroó 2018). This is revealed in Tynyanov's wellknown differentiation between the two kinds of function of the literary component (an element with literary quality, i.e. with the implication of its literariness), the autofunction and syn-function (Tynjanov (1971[1927]: 68)).

If the problem is elevated from the plane of the semiotics of text and textual corpuses (the literary history of literary texts) to that of semiotic research, i.e. it enters the domain of the semiotic analysability of literature and literary history, then the immanent analysis of literature should be understood as including the semiotic study of literary historical traditions (genres, discourse types, plots, characters, styles, etc.) at the level of the research object. At the same time, the study of the history of the traditions of the wide range of scholarly descriptions (literary study as having history, i.e. being a historical system) is also involved.

The immanent approach should cover both literary tradition (in its broadest sense - as systems) as well as the culture of the tradition made up by the history of various scholarly interpretations of literature. The immanent nature of the study of literature in this sense can be reformulated as the study of a particular cultural tradition in our case, literature as a cultural reality and literary scholarship belonging to literary culture itself (cf. again "Scientific investigation is not only an instrument for the study of culture but is also part of its object", Lotman et al. 2013:77). As a result, the claim for the so-called immanent analysis, strictly in this above-defined sense, must be considered to have validity for the contemporary semiotics of literature to be considered as one "series" in today's semiotics of culture. We will rely on the above-defined notion of "immanent" analysis, having in mind both the historical tradition of literary culture identified as a

5 Cf. Also Jakobson-Tynyanov's manifesto: "The history of a system is in turn a system" (Jakobson, Tynjanov 1987[1928]: 48). 
historical literary semiotic reality of literary texts, and the historical tradition of (semiotic) literary research. Together, they will be called the literary culture tradition.

In a new era of culture, characterized by the emergence and intensive development of new media and digital culture, which has contributed to the opening of new possibilities in creating an endless variety of multimodal and multimedial cultural texts, the problem lying in the correlation between the methodology of the "immanent" analysis of the part and the methodological approach taken for the overall interpretation of the whole multimodal/multimedial cultural space has become more acute. This contemporary cultural reality creates new questions and requirements in cultural semiotic research in general, as well as in the individual fields of cultural semiotic research, among them, literary semiotics. The question of a new kind of polyglotism of multimodal and multimedial screen culture, arising from translational processes from literary book culture ${ }^{6}$ (later we will come back to this issue under the theoretical label of transposition), raises the problem of the part and the whole in a new and more sophisticated way. For the conceptualization of the correlation between the part (visual, verbal, auditory etc.) and the whole, literary semiotics must rely on the knowledge and interpretation of the relevant literary cultural tradition of certain components preserving their semiotic literariness in the given multimodal/ visual construct and also the knowledge of cultural tradition belonging to the other cultural (semiotic) fields from which other components arise.

At the same time, the multiplication of part-whole relationships in culture can also be evaluated from the point of view of the processes of convergence and divergence. ${ }^{7}$ In multimodal and-medial constructs, the creation of the whole shows features of convergence, whereas the distribution of texts via separate channels embodies the cultural phenomenon of divergence. ${ }^{8}$ The analysability of the newest trends in contemporary culture through such recent concepts as, for example, convergence and divergence, can rightfully evoke the Formalist theoretical context with its interpretation

6 "I would say in relation to communication that we have come from a period in which there had been a stable constellation of the mode of writing with the medium of the book. That had led to a kind of naturalization in which to talk about the mode seemed like talking about the medium: the decline of the book equated with the decline of writing, for instance. The new constellation, culturally increasingly dominant, is that of the mode of the image and the medium of the screen. This will lead to quite new representational forms, new possibilities for communicational action, and new understandings of human social meaning making" (Kress 2004: 446).

7 For the interpretation of these concepts, see Jenkins 2006; for their actualization in the field of education, see, Kalogeras 2014; Jenkins 2009.

8 "Media content, or texts, that previously were considered as belonging to a specific medium are today produced for audiences through a range of different distribution techniques" (Bolin 2007: 244). 
of the relatedness of the cultural parts to each other and the cultural wholes to which they pertain. All this can be further explored within the framework of problems addressed in Juri Lotman's (and the Tartu-Moscow School's) theory of cultural dynamics.

It is important to stress that in the contemporary constellation of the creation of new artistic cultural products outlined above and their semiotic research (beside multimedial and -modal texts all kinds of transmedial translational/transpositional processes must be taken into account), semiotics of literature can rightfully stress the urgency of allowing the evaluation of par excellence literary culture traditions (cf. the artistic and scientific traditions characteristic of literary culture seen in its "immanent" interpretation) in its specific research domain. These methodological considerations, as we can see, arise in the context of the new cultural circulation of literary texts and in the dynamics of their transformation into new cultural products, coming into being through various kinds of textual transpositions. These processes affect the constant transfiguration of the correlations between the cultural part (literary culture) and the cultural whole. Taking it on a smaller scale, we can state that this concerns the relationship between a particular literary text functioning as a whole and new artistic cultural texts within which this very text is converted into various parts. In the light of this problem-complex, the Formalist and the Tartu-MoscowSchool heritage in cultural semiotics can be reevaluated from the perspective of the way in which immanent analysis was conceptualized and practised, forming a part of literary culture tradition as a historical system.

Highlighting this methodological aspect of literary semiotics is not only necessary in the interpretation of contemporary culture, but also indispensable in making a new initiative to define the disciplinary identity of literary semiotics and its status within the domain of cultural semiotics. It has been argued that all this is closely linked to the problem of literary dynamics, which concerns not simply the dynamics of the circulation of literary texts in culture, but also the transformation of the semiotic literariness of the text in new cultural constructs. To define the transformation of this semiotic literariness and its new function in new constructs, we necessarily rely on an understanding of literary culture tradition conceived as tradition of artistic and scholarly heritage. This is the reason why, after a long period of the development of universal categories and transfield notions, contributing to semiotic analyses of cultural phenomena belonging to various individual fields, by today it appears vitally important to take another "immanent" look at literary culture tradition regarded as a dynamic historical system. This approach is expected to open up new perspectives for more precise criteria in the disciplinary identification of literary semiotics.

As a result, new perspectives can also be expected to arise in drawing the demarcation lines between literary semiotics and other fields of cultural semiotics, on the one hand, and between the semiotics of literature and cultural semiotics as a whole, on the other. The problematization of the methodology of establishing correlation 
between the cultural whole and its parts at the level of scientific description can be heard from researchers of other cultural fields as well. Within the framework of transmedial narratological investigations, Herman (2004: 51) argues for the mediaspecific study of narratives: "[...] although narratives in different media exploit a common stock of narrative design principles, they exploit them in different, mediaspecific ways, or rather, in a certain range of ways, determined by the properties of each medium." Compare this with C. A. Scolari's statement reflecting the idea of the lack of "universal transmedia experiences":

Transmedia narrative worlds are a real challenge for communication studies, in particular for narratology and semiotics. Like most media studies, narratology and semiotics have also proposed monomediatic approaches. We have many specific semiotics (semiotics of radio, semiotics of television, semiotics of cinema, semiotics of theater, etc.) but we don't have a semiotics of transmedia experiences. (Scolari 2013: 47)

In our opinion, in the case of literary semiotics a greater emphasis on the involvement of literary culture tradition (i.e. returning from universal categories to field-specific categories) may lead to a better balance in the coexistence of two methodological trends: (1) moving from individual cultural fields to the interpretation of cultural phenomena in universal categories (cf. text, narrative, mythology, trope, chronotope, etc.), emphazing the common nature of diverse cultural texts; (2) giving priority to the interpretation of the cultural tradition of the sources from which the particular elements of complex cultural constructs emerge.

The latter orientation of being involved more deeply and substantially in the methodological repertoire is reflected in the title of this section in the present paper, conveying the message of reversing the methodological track.

\section{Analogy between text and culture: Further aspects of the theoretical heritage}

We are returning to the problem of the correlation of text and culture and their mutual functional activities, both in artistic cultural practice and in science, offering analytical descriptions through the application of the notions of text and culture. Proceeding from the same authors of Formalist-Structuralist theory and its heritage (Tynyanov, Jakobson, Lotman), but referring also to Bakhtin, we put the question of the interrelation of text and culture in the light of textual and cultural dynamics in a more concrete fashion and call attention to some of these authors' key concepts. They contribute to the identification of some interpretations of the analogy between 
text and culture, drawn within the framework of the explanation of the phenomena characterized by textual/cultural dynamics. We will not pursue the development of the examined notions and their transformative redefinitions in further evolutionary processes of the relevant points of theory.

As contextualized above, in Tynyanov's theory the literary work is thought to be related to literature as a whole system through the notion of function pertaining to a textual element. The dynamics of culture cannot be interpreted without taking into account the reciprocal links between the individual "series" within it - this, as also discussed above, already concerns the problem of the relationship between literature as a whole system and other cultural fields in the overall realm of culture. So, cultural dynamics, conceived as the correlation of works or corpuses of texts constituting whole cultural series, and their interrelation with culture as a whole, can be interpreted in terms of dynamics through function directly (syn-function and autofunction) or indirectly (literature with the functions of its components entering the whole cultural system in a "system of systems"; cf. also the role of texts interpreted in respect of their status in the centre and periphery, see first in Tynyanov 1977[1924]). The creating of an analogy between the literary work (text) and culture, with their dynamic relationships, evolves as a tripartite chain: (1) a component of the literary work; (2) an analogous component of literature - as a result of the analogy, literature must be seen to involve the affiliation of the particular literary work to the whole system of literature; (3) the whole dynamic construct indicated under (2) becomes a component of the overall culture. The creation of analogies linking text $(s)$ and culture is based on the presumption of inclusiveness (literary component $\rightarrow$ literary work $\rightarrow$ literature as a system $\rightarrow$ culture as a system).

In the conceptualization of the literary component, consequently, the presupposition of literariness should be implied (though the term itself is not used in the given context), since, through the triphasal dynamic inclusion of text in culture, it is the integration of literature as a whole system which is kept alive in its dynamism. It can be taken for granted, then, that the literary component at the beginning of the integrational dynamic development must emphatically carry the trait of literariness, which, as Tynyanov's integrational chain testifies, ensures in the long run the status of literature as an integral part of culture. There is no contradiction in this clarification even if we treat the dynamics of the exchange between the central and the peripheral in the cultural space. Once again, from this point of view, the question of the potentialities of the literariness (endowing a peripheral literary phenomenon [text] or a non-literary phenomenon with the above analysed functionality) must be part of the interpretation. It would hardly be imaginable to think of the dynamic cultural exchange between the central and the peripheral without assuming the functionality of the literariness at least potentially present in the phenomena concerned. 
The problematization of the centre and the periphery is closely linked to the interpretation of the dominant. This notion cannot be separated from Tynyanov's theoretical ideas, but now we are reminded of the classic definition by Jakobson in his article "The dominant". It must be stressed in this context that it is a concept enabling us to grasp the dynamics of hierarchical regulation both in an individual text (where the dominant "specifies" the work, cf. Jakobson 1987[1971]: 41) and culture (where the dominant is to be searched for "in the poetic work of an individual artist and [...] in the poetic canon, the set of norms of a given poetic school" and "also in the art of a given epoch, viewed as a particular whole", Jakobson 1987[1971]: 42). Concerning the individual text, the dominant (a) "is a focusing component of the individual work of art: it rules, determines and transforms the remaining components", being the dominant, the operational rule which "guarantees the integrity of the structure" (Jakobson 1987[1971]: 41), and that includes that (b) the aesthetic function in its capacity of the dominant "permits us to determine the hierarchy of diverse linguistic functions within the poetic work" (Jakobson 1987[1971]: 43). The phenomenon of the dominant is responsible for the nature and the constant transformation of "the relationship between a poetic work and other verbal messages" (Jakobson 1987[1971]: 43). The shifting dominants thus explain cultural evolution in various aspects (for example, the evolution of genre canons). Through the concept of the shifting dominant a dynamic "definition of the artistic work as compared to other sets of cultural values" (Jakobson 1987[1971]: 43) can be achieved. This view of the double function of the dominant, inseparably relating the individual textual and the general cultural dynamics as a whole (i.e. the view of the reciprocity of dynamic processes in text and culture), is embedded in the conceptualization of two aspects of dynamics: (a) hierarchy, (b) integration. It is the dynamics concerning hierarchy and integration which can be explained through the concept of the dominant, projecting the individual work and the culture upon each other: from one perspective, cf. "The hierarchy of artistic devices changes within the framework of a poetic genre; the change, moreover, affects the hierarchy of poetic genres" (Jakobson 1987[1971]: 44); this kind of understanding is deeply rooted in the formalist view of integration: the identification of the dominant may reveal "the multiple functions of a poetic work with a comprehension of its integrity, that is to say, that function which unites and determines the poetic work" (Jakobson 1987[1971]: 43). This, on the basis of Jakobson's "summary", can be traced back to Russian Formalist theory.

If, by drawing conclusions from the interpretation of the text-culture relationship in terms of dynamics, we wish to reach the point where we can discuss more general features, pertaining to the explanation of textual and cultural dynamics, then we can fix the notions of 'relationality' (see the reciprocal and multiple projection of 'function' 
and 'dominant' - all this engendering textual and cultural 'meaning'), 'inclusiveness/ integration' and 'hierarchy' in terms of which dynamics is interpreted.

In Bakhtin's conceptualization of dynamics the key concept is 'dialogue' (proving to be partly a metaphorical term for interpreting a wide range of 'relationality', cf. Holquist 2005; Velmezova 2015). This is explained throughout his oeuvre in the diverse aspects of the manifestations of textual and cultural dynamic reciprocality. At this point, we refer to an earlier article (Kroó 2016), that proposes a typology of four major realms in the interpretation of dialogicity in terms of dynamics (with its relationsip to aspects of semantic and semiotic ${ }^{9}$ dynamics).

This typology is based on the artistic word's most essential feature, that of being a word event ("событие самого слова", cf. "an event of discourse itself"). This reveals the dialogic nature of artistic word-utterance in its embodiment, beginning from the smallest verbal segment to the whole of the literary text, primarily the novel dialogization representing "marked forms for mixing and polemicizing with the discourse of another". A dialogue, according to Bakhtin's conviction:

[...] in artistic prose, and especially in the novel, [...] penetrates, from within the very way in which the word conceives its object and its means for expressing itself, reformulating the semantics and syntactical structure of discourse. Here dialogic inter-orientation becomes, as it were, an event of discourse itself, animating from within and dramatizing discourse in all its aspects. (Bakhtin 1981:284, cf. Bakhtin 2012: 37).

As inherent in the dialogic quality, we can reveal transformation, supplied with numerous explicit and implicit direct or metaphorical definitions conveying the idea of the dynamic activity realised by/in the word. This leads the word to give birth to new meaning conceived as a kind of transcendence based on the permanent modification and transfiguration of the expression and its content: "The theme is always transcendental to language [...] the entire utterance, like a speech performance, is directed at the theme" (Caryl Emerson's translation; ${ }^{10}$ cf. Medvedev [Bakhtin] 2000: 309). Dialogue engenders semantics in terms of emergence ("becoming" "становление"), concerning (a) the participants in the communicational situation, the subjects of the word, creating new sense, and also its addressee; (b) the word

9 For the first interpretation of the distinction between the semiotic and the semantic in Bakhtin, see Ivanov 1976.

10 The translator has made an important comment on the given passage: “Transcendental to' is used by Bakhtin as it is used in Idealist philosophy: an item unavailable to direct cognition because it lies beyond the boundaries of experience." We express our gratitude to Caryl Emerson for translating this and another passage below from Bakhtin for this article and also for her comment. 
itself in all of its dialogical relationships; and (c) the contexts of heteroglossia (a diversity of speech types ["разноречuе"] and also, the diversity of languages ["разноязычие”] and individual voices, i.e. multivoicedness [“разноголосииа”]). The theme - according to Voloshinov/Bakhtin "is a complex, dynamic system of signs that attempts to be adequate to a given instant of generative process. Theme is reaction by the consciousness in its generative process to the generative process of existence" (Vološinov 1973: 100, italics in the original; cf. Voloshinov [Bakhtin] 2000: 434).

This emergence/becoming in metaphoric terms is interpreted as "struggle" of "accents", resulting in "multiaccentuality" ("многоакиентность", Vološinov 1973: 23, cf. Voloshinov [Bakhtin] 2000: 366) in the form of "expressive intonation" (cf. “экспрессивные интонации”, Medvedev [Bakhtin] 2000: 326), and also non-dialogic abstract linguistic meaning can be, for example, "subsumed under theme and torn apart by theme's living contradictions so as to return in the shape of a new meaning" (Vološinov 1973: 106; cf. Voloshinov [Bakhtin] 2000: 440). What can be grasped through the notion of the many-faceted dialogicity, is the strongest ontological and epistemological force in the transformational dynamics of creation and the emergence/ becoming ("становление") of the addresser and the addressee of the dialogical word, and the emergence and development of permanently transfiguring words/texts seen on a scale taking numerous variants and pertaining to various cultures. This can be conceptualized in terms of continuity (cf. the word - the translational context of the word - and the new word, etc.). In this spirit, processes of cultural evolution can be identified and their historicity clarified. ${ }^{11}$

In an attempt to show a possible typology, starting from literary text dynamics inseparably related to the broader framework of cultural dynamics, we call attention to the following perspectives.

(1) The conceiving by the word of its object ("кониипирование словом своего предмета") - here dialogicity is revealed in the object of the utterance, manifesting itself in the interaction with "the already bespoke quality" of the object (Bakhtin 1981: 331; see "оговоренность", cf. Bakhtin 2012: 85) - "For the prose writer, the object is a focal point for heteroglot voices among which his own voice must also sound" (Bakhtin 1981: 278; cf. Bakhtin 2012: 32); compare this with the idea: "And an artistic representation, an 'image' of the object, may be penetrated by this dialogic play of verbal intentions that meet and are interwoven in it [...]" (Bakhtin 1981: 277; cf. Bakhtin 2012: 31); and see also:

11 Caryl Emerson points to the fact that "[w] hat Baxtin seems to have sought was newness that did not stress the autonomy of the present or the future, but that addressed the past in unanticipated, productive ways - and invited similar approaches to itself" (Emerson 1988: 507-508). The idea of unanticipatedness was a source of inspiration coming from Bakhtin to Lotman. For the relationship between Lotman's and Bakhtin's thinking, see Egorov 1999. 
The word, breaking through to its own meaning and its own expression across an environment full of alien words and variously evaluating accents, harmonizing with some of the elements in this environment and striking a dissonance with others, is able, in this dialogized process, to shape its own stylistic profile and tone. (Bakhtin 1981: 277; cf. Bakhtin 2012: 31)

In the domain of semiotics this leads to the possibility of explaining literary meaninggeneration in internal and external contexts, in the light of dialogical relationships emerging in various aspects:

The problem of understanding (the problem of another's word). Two consciousnesses. The first consciousness (the object that is understood and interpreted) is not simply another's individual consciousness, but a specific cultural consciousness, the consciousness of a specific epoch, cultural sector, specific social group. - The meeting of two consciousnesses, of two times (two epochs); both co-participate creatively and both are mutually enriched. - The theme is always transcendental to language [...] the entire utterance, like a speech performance, is directed at the theme. (Caryl Emerson's translation; cf. Bakhtin 2002: 402-403)

To conclude under this first category of the given typological systematization, we mean the cultural-semantic dynamics of the word. This also includes the historical cultural dynamics (genre memory).

(2) Dialogue, as the correlation between the self and the other, in the sense of the active mutual (responsive) understanding of the communicational partners - this can be labelled as the communicational-hermeneutic semantic dynamics of the word. In a literary text this perspective of semantic dynamics might involve the interpretation of the explicit semantic model of the dialogue, but may also imply the relationship between the text and the reader in the course of reception, as well as the various semantic models of this relationship as created in the literary text (for example through the modelling of the interpretative competence of heroes, narrators, etc.). As compared to the dynamics indicated above in (1), a significant difference can be detected in this respect: "This new form of internal dialogism of the word is different from that form determined by an encounter with an alien word within the object itself: here it is not the object that serves as the arena for the encounter, but rather the subjective belief system of the listener" (Bakhtin 1981:282; cf. Bakhtin 2012: 36).

(3) The language of the novel as a system - here, dynamics is engendered by the systematization of the components revealing themselves in structures of heteroglossia ("разноречие"), language and linguistic diversity ("разноязычие") and multivoicedness ("разноголосииа"), embodied in various narrative, character, chronotopic, motivic, intertextual, etc. formations integrated into a complex system within the text. This can be conceptualized as the system dynamics of the literary text - cf. 
These distinctive links and interrelationships between utterances and languages, this movement of the theme through different languages and speech types, its dispersion into the rivulets and droplets of social heteroglossia, its dialogizationthis is the basic distinguishing feature of the stylistics of the novel (Bakhtin 1981: 263; cf. Bakhtin 2012: 16);

See further:

And this stratification and heteroglossia, once realized, is not only a static invariant of linguistic life, but also what insures its dynamics: stratification and heteroglossia widen and deepen as long as language is alive and developing. Alongside the centripetal forces, the centrifugal forces of language carry on their uninterrupted work; alongside verbal-ideological centralization and unification, the uninterrupted processes of decentralization and disunification go forward. (Bakhtin 1981: 272; cf. Bakhtin 2012: 25).

In its essence, this feature of textual dynamics ensures the semantic dynamics of integration.

(4) Integration, as also demonstrated in the previous quotation, in itself implies processes of decentralization and disjunction. Bakhtin's interpretation of dynamics is significantly characterized by the identification of textual and cultural movements, the interpretation of which can be seen from the point of view of the semantic dynamics of distancing. This dynamics is embodied in the orientation of the word (utterance, text) beyond itself. Here the explanation of the modelling of the word can be mentioned (cf. the word about the word), which makes it possible to speak, in a newer terminology, about the metaconstructions analysed by Bakhtin. In this respect we can take into consideration all of the manifestations when metawords/-utterances/-texts referencing or in some way reflecting upon other words/utterances/texts/languages/cultures are voiced. This may lead to the construction of whole metatexts (metacultural texts) in the literary work. ${ }^{12}$

To sum up the investigational orientations examined in Bakhtin's theory, we can conclude that in all the revealed aspects of text dynamics (relying on the function of the word in the context of the utterance), text and culture are, and must be, read side by side. The dialogical nature of the word cannot be conceived without its correlation with an infinite number of cultural components entering the word in the course of the dynamic interaction of text and culture.

Finally, we will not dwell long on Lotman's well-known interpretation of the interrelation of text and culture. His conceptualization is deeply rooted in Tynyanovian, Jakobsonian and Bakhtinian heritage. When remembering Lotman's inter-

12 We apply the notion/term 'distancing' in a sense different from Kristeva 2001: 223. 
pretation of textual and cultural dynamics, it is important to pay attention to textual hierarchization (we could call this interlevel dynamics), presupposing the distancing and integrational semantic processes. These involve meaning exchanges entailing transformation in various forms of communication between text and culture. Lotman's terms of the extratextual and the intratextual, the stress put on the explanation of the function of textual borders and the conviction of the analysability and interpretability of culture in terms of textual processes, shown in the perspective of cultural evolution, stand alongside the clarification of the functionality of texts within culture and culture within a single text. How the part-whole problematics is an organic component of the given issue, that has been dealt with earlier in this paper.

\section{Text and culture - new perspectives}

The components of the theoretical heritage discussed above, with their emphasis on the two-direction movement of literary texts from text to culture and from culture to text, show conspicuous common features, speaking about the nature of literary dynamics. These are linked to operations of inclusiveness/integration, distancing and hierarchization leading to transformation (transgressing, "going beyond"). Our suggestion would be to establish broad categories in which the most significant aspects of dynamics can be studied and classified. If these categories are set up, it is possible to put side by side the examination of the dynamics working within the literary text (with its internal interaction with culture) and the investigation of the dynamics working through the literary text when it goes beyond itself, entering the larger cultural space in cultural-textual communicational acts. This may prove to be a productive way of finding an answer to the dilemmas of the disciplinary identification of semiotics of literature and semiotics of culture.

The main categories under which the crucial aspects of textual/cultural dynamics will be examined are the following:

(1) mediation;

(2) transposition;

(3) temporality-spatiality.

Some of their textual/cultural phenomena, to which we plan to return in later papers, include:

mediation: cultural connections, relational semantics, interpretation and translation as mediation, the dialogue between addresser and addressee of cultural texts and communication modelled in them, mediatory structures, etc.;

transposition: meaning generation, transferring shifts, semantic transformations, interlevel dynamics, text-metatext, structural-semantic inclusion, integration, hierarchization, translation as transposition, transmedial translation, etc; 
temporality-spatiality: processuality, disruption, disjunction, statics/stillness vs. dynamics, narration vs. description, gradual change vs. explosive change ("explosion"), the temporal-spacial, chronotopes, ${ }^{13}$ centre-periphery, etc.

In this paper we have referred to the historical context of a cultural heritage which originates in Russian Formalism. However, investigational efforts put into "new literary semiotics", have also voiced the strength and the validity of other directions in theoretical heritage. These are linked to the Peircean tradition and the pragmatic orientation in literary semiotics. In his overview of a new methodological trend, emerging in the last decade of the 20th and the first decade of this century, Harri Veivo identifies a new phase of development for literary semiotics, bringing about new inquires in three major fields: "[...] the analysis of language-world relationship, imaginative reading, and interpretation as dialogic production of shared knowledge" (Veivo 2007: 41). There has been significant research done in these domains, ${ }^{14}$ and also in revealing that kind of research productivity which theoretically and methodologically must be linked to Peirce's semiotics. The categories set up for a synthetizing investigation into literary/cultural dynamics and semiotic literariness can be regarded as facilitating the scope of the benefit to be taken from the achievements of these two parallel, and in many regards overlapping (cf. Kiryushchenko 2012), methodological fields (each representing its own special foci in common fields of research). Mediation, semantic motivation, processuality, the dialogic/polylogic nature in artistic referentiality, the text-reader relationship, etc. are issues which are expected to be investigated in every aspect of the research object (dynamics and semiotic literariness) raised in the present paper and included in the three major categories suggested above. These are, consequently, not categories which divide, drawing a rigid demarcation line between the so-called structuralist and pragmatic semiotic

13 Cf. "...the Bakhtinian heritage helps contemporary semiotics of culture in understanding culture and text as temporal-spatial (chronotopical) systems" (Torop 2017: 322).

14 Cf. Fisette (2007: 68): “In regard to the semiotics ensuing from Peirce's works, elaboration is much less advanced. This theory corpus has been constituted, as an object of knowledge, for less than twenty-five years. The consideration of the literary object under such perspective is new or at least very recent (see Johansen 2002; Veivo 2001; Fisette 1996a; Francour and Francœur 1993; and Haley 1988)." [Cf. the quoted works: Johansen, Jørgen Dines 2002. Literary Discourse: A Semiotic Approach to Literature. Toronto: University of Toronto Press; Veivo, Harri 2001. The Written Space: Semiotic Analysis of the Representation of Space and its Rhetorical Functions in Literature (Acta Semiotica Fennica X). Helsinki: International Semiotics Institute; Fisette, Jean 1996. Pour une pragmatique de la signification. Suivi d'un choix de textes de Charles S. Peirce en langue française. Montréal: XYZ éditeur; Francœur, Louis; Francœur, Marie 1993. Grimoire de l'art. Grammaire de lêtre. Québec: Presses de l'Université Laval/Klincksieck; Haley, Michael Cabot 1988. The Semeiosis of Poetic Metaphor (Peirce Studies 4). Bloomington: Indiana University Press]. 
literary studies. On the contrary, that part of the formalist-structuralist tradition which we have examined in this introductory paper explaining our future direction, demonstrates the possibility of a fruitful synthesis to be achieved in literary semiotics. ${ }^{15}$ To identify the real scope of this semiotic field as an independent discipline may only be achieved on the basis of this synthesis. ${ }^{16}$

\section{References}

Alexander, Bryan 2011. The New Digital Storytelling: Creating Narratives with New Media. Santa Barbara: Praeger.

Avtonomova, Natalia 2009. Otkrytaya struktura: Jakobson-Bakhtin-Lotman-Gasparov. Moscow: ROSSPEN. [Открытая структура: Якобсон-Бахтин-Лотман-Гаспаров. Москва: Российская политическая энциклопедия (РОССПЭН).]

Backe, Hans-Joachim 2015. The literary canon in the age of new media. Poetics Today 36(1/2): $1-31$.

Bakhtin, Mikhail 1981. Discourse in the novel. In: Bakhtin, Mikhail, The Dialogic Imagination. (Emerson, Caryl; Holquist, Michael, trans.) Austin: University of Texas Press, 259-422.

- 2002. Sobranie sochinenij v 7 tomah. Vol. 6. Problemy poetiki Dostoevskogo 1963. Raboty 1960-h - 1970-h gg. Moscow: Russkie slovari, Yazyki slavyanskih kul'tur. [Бахтин, М. М. 2002. Собрание сочинений в 7 томах. Т. 6. Проблемы поэтики Достоевского 1963. Работы 1960-х - 1970-х г2. Москва: «Русские словари», «Языки славянских культур».]

- 2012. Sobranie sochinenij $v 7$ tomax. Vol. 3. Teoriya romana 1930-1961 gg. Moscow: Yazyki slavyanskih kul'tur. [Бахтин, М. М. 2012. Собрание сочинений в 7 томах. Т. 3. Теория романа 1930-1961 г2. Москва: «Языки славянских культур».]

Balcerzan, Edward 2016. Literariness: Models, Gradations, Experiments. (Gauger, Soren, trans.) Frankfurt am Main: Peter Lang.

Bolin, Göran 2007. Media technologies, transmedia storytelling and commodification. In: Storsul, Tanya; Stuedahl, Dagny (eds.), Ambivalence Towards Convergence Digitalization and Media Change. Göteborg: Nordicom, 237-248.

Bruhn, Jørgen 2016. The Intermediality of Narrative Literature: Medialities Matter. London: Palgrave Macmillan.

15 Cf. Jakobson's statement from 1952: “The greatest pioneer of structural linguistic analysis was Charles Sanders Peirce” (Jakobson 1976[1952]: 1534-1535). Since Jakobson's suggestion to take into account both the Saussurean and the Peircean conceptualizations, numerous works have been published on the possibility and necessity of observing the two directions together cf., e.g. Liszka 1981.

16 Fisette (2007: 68) speaks of a complementarity: "I would like to present, with an attitude of complementarity to that other place of semiotics, some reflections and propositions that open the way to new relations between the elaboration of a signification theory and the practices of literature: writing and reading". It is still a valid and an even more topical research task to show what kind of synthesis can be reached within a presupposed individual disciplinary field to be called the semiotics of literature. 
Danow, David K. 1986. Dialogic perspectives: The East European view (Bachtin, Mukařovský, Lotman). Russian Literature 20: 119-142.

DeJean, Joan 1977. In search of the artistic text: Recent works by Lotman and Uspensky. SubStance 6/7(17): 149-158.

Egorov, Boris F. 1999. Bakhtin i Lotman. In: Egorov Boris F., Zhizn' i tvorchestvo Yu. M. Lotmana. Moscow: Novoe literaturnoe obozrenie, 243-258. [Егоров, Б. Ф. 1999. Бахтин и Лотман. In: Жизнь и творчество Ю. М. Лотмана. Москва: «Новое литературное обозрение», 243-258.]

Eichenbaum, Boris 2001. The theory of the "formal method". In: Leitch, Vincent B. (ed.), The Norton Anthology of Theory and Criticism. (Lemon, Lee T.; Reis, Marion J., trans.) New York: W. W. Norton \& Company, 1062-1080.

Elleström, Lars (ed.) 2010. Media Borders, Multimodality and Intermediality. Basingstoke: Palgrave Macmillan.

Emerson, Caryl 1988. Problems with Baxtin's poetics. The Slavic and East European Journal 32: $503-525$.

Fisette, Jean 2007. Literary practice on the immediate horizon of the elaboration of semiotics: Peirce's meetings with a few great authors. Semiotica 165(1/4): 67-89.

Freidenberg, Olga 1997. Image and Concept: Mythopoetic Roots of Literature. (Moss, Kevin, trans.) Amsterdam: Harwood Academic Publishers.

Gherlone, Laura 2016. Vygotsky, Bakhtin, Lotman: Towards a theory of communication in the horizon of the other. Semiotica 213: 75-90.

Hansen-Löve, Aage 2001. Russkij formalizm: Metodologicheskaya rekonstruktsiya razvitiya na osnove printsipa ostraneniya. Moscow: Yazyki russkoj kul'tury, CEU. [Русский формализм. Методологическая реконструкиия развития на основе приниипа остранения. Москва: Языки русской культуры, CEU.]

Heinen, Sandra; Sommer, Roy (eds.) 2009. Narratology in the Age of Cross-Disciplinary Narrative Research. (Narratologia 20.) Berlin: Walter de Gruyter.

Herman, David 2004. Toward a transmedial narratology. In: Ryan, Marie-Laure (ed.), Narrative Across Media: The Languages of Storytelling. Lincoln: University of Nebraska Press, 47-75.

Holquist, Michael 2005. Dialogism: Bakhtin and his World. (2nd ed.) London: Routledge.

Ivanov, Vyacheslav Vsevolodovich 1976. The Significance of M. M. Bakhtin's Ideas on Sign, Utterance, and Dialogue for Modern Semiotics. (Papers on Poetics and Semiotics 4; TolstajaSegal, Elena, trans.) Tel-Aviv: Israeli Institute for Poetics and Semiotics, Tel-Aviv University. Jakobson, Roman 1976[1952]. A few remarks on structuralism. Modern Language Notes 91: 1534-1539.

- 1987 [1971]. The dominant. In: Pomorska, Krystyna; Rudy, Stephan (eds.), Language in Literature. Cambridge: The Belknap Press of Harvard University Press, 41-46.

Jakobson, Roman; Tynjanov, Jury 1987[1928]. Problems in the study of language and literature. In: Pomorska, Krystyna; Rudy, Stephen (eds), Language in Literature. Cambridge: The Belknap Press of Harvard University Press, 47-49.

Jenkins, Henry 2009. Confronting the Challenges of Participatory Culture: Media Education for the 21st Century. Cambridge: The MIT Press.

Kalogeras, Stavroula 2014. Transmedia Storytelling and the New Era of Media Convergence in Higher Education. Basingstoke: Palgrave Macmillan. 
Kiryushchenko, Vitaly 2012. Peirce's semiotics and the Russian Formalism: Points of convergence. In: Proceedings of the 10th World Congress of the International Association for Semiotic Studies (IASS/AIS). Universidade da Coruña (España/Spain), 1317-1322.

Kress, Gunther 2004. Media discourse - extensions, mixes, and hybrids: Some comments on pressing issues. Text 24(3): 443-446.

Kress, Gunther; Leeuwen, Theo van 2006. Reading Images: The Grammar of Visual Design. London: Routledge.

Kristeva, Julia 2001[1967]. Bakhtin, slovo, dialog i roman. In: Burlaka, D. K. (ed.), M. M. Bakhtin. Pro et contra. T. 1. Sankt-Peterburg: Izdatel'stvo Russkogo hristianskogo gumanitarnogo instituta, 213-243. [Кристева, Ю. Бахтин слово, диалог и роман. In: $M$. M. Бахтин. Pro et contra. T. 1. Санкт-Петербург: Издательство Русского христианского гуманитарного института, 213-243.]

Kroó, Katalin 2016. "Dialogichnost" kak semanticheskaya i semioticheskaya dinamika literaturnogo teksta: Semiotika literatury v kontekste lingvistiki i yazykovoj kommunikatsii. Studia Slavica Academiae Scientiarum Hungaricae 61(1): 159-190. [«Диалогичность» как семантическая и семиотическая динамика литературного текста. Семиотика литературы в контексте лингвистики и языковой коммуникации. Studia Slavica Hung. 61(1): 159-190].

- 2018 (in print). From the formalist to the semiotic theory of literature. Communications. Vol. 103: Le formalisme russe cent ans après (Depretto, Catherine; Pier, John; Roussin, Phillippe, eds.).

Liszka, Jakób 1981. Peirce and Jakobson: Towards a structuralist reconstruction of Peirce. Transactions of the Charles S. Peirce Society 17(1): 41-61.

Lotman, Juri 1975. Notes on the structure of literary text. Semiotica 15(3): 199-205.

- 1988. The semiotics of culture and the notion of text. Soviet Psychology 26(3): 52-58.

- 2009. Culture and Explosion. (Clark, Wilma, trans.) (Semiotics, Communication and Cognition 1.) Berlin: Mouton de Gruyter.

- 1990. Universe of the Mind: A Semiotic Theory of Culture. (Shukman, Ann, trans.; Eco, Umberto, intr.) London: L. B. Tauris \& Co Ltd.

Lotman, Juri; Ivanov, Vjacheslav V.; Pjatigorskij, Aleksandr M.; Toporov, Vladimir N.; Uspenskij, Boris A. 2013[1973]. Theses on the semiotic study of cultures (as applied to Savic texts). In: Salupere, Silvi; Torop, Peeter; Kull, Kalevi (eds.), Beginnings of the Semiotics of Culture. (Tartu Semiotics Library 13.) Tartu: University of Tartu Press, 53-77.

Lotman, Juri; Uspensky, Boris 1978. Myth - name - culture. Semiotica 22(3/4): 211-233.

Mandell, Laura 2015. Breaking the Book: Print Humanities in the Digital Age. Chichester: WileyBlackwell.

Medvedev, Pavel N. [Bakhtin, Mikhail M.] 2000. Formal'nyj metod v literaturovedenii. Kriticheskoe vvedenie v sotsiologicheskuyu poetiku. In: Bakhtin pod maskoj. Moscow: Labirint, 349-486. (Leningrad: Priboj, 1928.) [Медведев, П. Н. Формальный метод в литературоведении. Критическое введение в социологическую поэтику. In: Бахтин под маской. Москва: «Лабиринт», 195-348. (Ленинград: «Прибой», 1928.)]

Meletinskij, Eleazar M. 2000. The Poetics of Myth. (Lanoue, Guy; Sadetsky, Alexandre, trans.) New York: Routledge.

Piatigorsky, Alexander 1993. Mythological Deliberations: Lectures on the Phenomenology of Myth. London: University of London. 
- 1996. Zametki iz 90-h o semiotike 60-h. In: Pyatigorskij, Alexander. Izbrannye trudy. Moscow: Yazyki russkoj kul'tury, 53-57. [Пятигорский, Александр. Заметки из 90-х о семиотике 60-x. In: Пятигорский, Александр. Избранные труды. Москва: Языки русской культуры, 53-57.]

Ryan, Marie-Laure 2001. Narrative as Virtual Reality Immersion and Interactivity in Literature and Electronic Media. Baltimore: The Johns Hopkins University Press.

Salupere, Silvi; Torop, Peeter 2013. On the beginnings of the semiotics of culture in the light of the Theses of the Tartu-Moscow School. In: Salupere, Silvi; Torop, Peeter; Kalevi Kull (eds.), Beginnings of the Semiotics of Culture. (Tartu Semiotics Library 13.) Tartu: University of Tartu Press, 15-37.

Scolari, Carlos A. 2013. Lostology: Transmedia storytelling and expansion/compression strategies. Semiotica 195: 45-68.

Segal, Dmitrij 2011. Puti i vekhi: Russkoe literaturovedenie v dvadtsatom veke. Moscow: Vodolei. [Сегал, Дмитрий. Пути и вехи: Русское литературоведение а двадиатом веке. Москва: Водолей.]

Sonesson, Göran 2008. Beyond methods and models: Semiotics as a distinctive discipline and an intellectual tradition. Signs 2: 277-319.

Thon, Jan-Noël 2016. Transmedial Narratology and Contemporary Media Culture. Lincoln: University of Nebraska Press.

Toporov, Vladimir 1978. On Dostoevsky's poetics and archaic patterns of mythological thought. (Knight, Susan, trans.) New Literary History 9(2): 333-352.

Torop, Peeter 2015. Cultural semiotics. In: Sharifian, Farzad (ed.), The Routledge Handbook of Language and Culture. London: Routledge Taylor \& Francis Ltd, 170-180.

- 2017. Semiotics of cultural history. Sign Systems Studies 45(3/4): 317-334.

Tynjanov, Jurij 1971[1927]. On literary evolution. In: Matejka, Ladislav; Pomorska, Krystyna (eds.), Readings in Russian Poetics: Formalist and Structuralist Views. Cambridge: The MIT Press, 66-78.

- 1977[1924]. Literaturnyj fakt. In: Tynyanov, Jurij N. Poetika. Istoriya literatury. Kino. Moscow: Nauka, 255-269. [Тынянов, Ю. Н. Литературный факт. In: Тынянов, Ю. Н. Поэтика. История литературы. Кино. Москва: Наука, 255-269.]

Veivo, Harri 2007. The new literary semiotics. Semiotica 165(3/4): 41-55.

Velmezova, Ekaterina 2015. The Bakhtinian dialogue revisited: A (non-biosemiotic) view from historiography and epistemology of humanities. In: Velmezova, Ekaterina; Kull, Kalevi; Cowley, Stephen. J. (eds.), Biosemiotic Perspectives on Language and Linguistics. (Biosemiotics 13.) Cham: Springer, 275-290.

Vološinov, Valentin N. 1973. Marxism and the Philosophy of Language. (Matejka, Ladislav; Titunik, I. R., trans.) New York: Seminar Press.

- [Bakhtin, Mikhail M.] 2000 = Voloshinov, Valentin N. Marksizm i filosofiya yazyka. Osnovnye problemy sotsiologicheskogo metoda v nauke o yazyke. In: Bakhtin pod maskoj. Moskva: Labirint, 349-486. (Leningrad: Priboj, 1929.) [Волошинов В. Н. Марксизм и философия языка. Основные проблемы социологического метода в науке о языке. In: Бахтин под маской. Москва: «Лабиринт», 2000: 349-486. (Ленинград: «Прибой», 1929).]

Wolf, Werner 1999. A Study in the Theory and History of Intermediality. Amsterdam: Rodopi. 
Wolf, Werner; Bernhart, Walter (eds). 2006. Framing Borders in Literature and Other Media. Amsterdam: Rodopi.

Zenkin, Sergei 2004. Vvedenie. In: Zenkin, Sergei (ed.), Russkaya teoriya: 1920-1930-e gody. Moskva: RGGU, 7-10. [Зенкин, Сергей 2004. Введение. In: Русская теория: 1920-1930е годы. Москва: РГГУ, 7-10.]

Portis-Winner, Irene; Winner, Thomas G. 1976. The semiotics of cultural texts. Semiotica 18(2): 101-156.

\section{Динамика текста - неустанный вызов семиотике литературы}

В статье анализируется проблема текстовой и культурной динамики в контексте семиотической литературности, являющейся объектом изучения в последующих работах авторов настоящей статьи по семиотике литературы. Целью исследования данной проблематики является дисциплинарное определение семиотики литературы как автономной сферы науки и ее связи с семиотикой культуры. Первым шагом является раскрытие корреляции между текстом/культурой посредством понятия динамики, как ее можно исторически реконструировать на основе традиций формалистской и структуралистской теории (Тынянов - функция, Якобсон - доминанта), а также наследия Ю. Лотмана (соотношение текста - культуры) и М. Бахтина (диалог). Понятия инклюзивности/интеграции, дистанцирования и иерархизации интерпретированы в упомянутом теоретическом контексте. На данных традициях основываются три базовые категории для достижения анализируемости текстовой/культурной динамики и намечаются дальнейшие аспекты функции динамики. Предложенная категоризация допускает параллельное изучение динамики литературного текста и культуры в более широком масштабе: (1) посредничество - различные культурные контакты, семантика, заложенная в корреляциях разного типа, интерпретация и перевод как формы посредничества, диалог между отправителем и получателем текста культуры и моделированных в нем участников коммуникации, структуры посредничества и т.д.; (2) транспозиция - порождение значения, сдвиги, приводящие к смысловым переносам, семантические трансформации, межуровневая динамика, соотношение 'текст-метатекст', стурктурно-семантическое вовлечение, интеграция, иерархизация, перевод как транспозиция, трансмедийный перевод и т.д.; (3) темпоральность-пространственность - процессуальность, прерывание, разъединение, статика/приостановленность vs. динамика, повествование vs. описание, постепенное изменение vs. взрыв, система пространственно-временных мотивов, хронотопы, центр-периферия и т.д.; Предложенная классификация и имплицированное понятийное деление могут послужить для синтеза «структуралистской» и пирсовской теоретической и методологической направлений в семиотике литературы. Тем самым может быть дан толчок для более точного определения дисциплинарных рамок семиотики литературы и приобретения новых средств анализа при толковании специфики литературно-семиотического свойства определенных компонентов (или целостного художественного оформления) мультимодальных и трансмедийных явлений. Аналогично может исследование привести к большему осознанию необходимости методологического сосуществования подходов, (1) направленных от определенной сферы культуры (традиции литературной культуры) к общей семиотике культуры и (2) направленных на 
возвращение от универсальных трансдисциплинарных понятий к литературной культуре, включая исторические традиции как искусства (объектный уровень), так и научной интерпретации (метауровень).

\section{Teksti dünaamika - kirjandussemiootika lakkamatu väljakutse}

Artikkel analüüsib teksti ja kultuuri dünaamikat semiootilise kirjanduslikkuse kontekstis. Semiootiline kirjanduslikkus on autorite kirjandussemiootiliste ühistööde jätkuv uurimisobjekt. Uurimistöö eesmärgiks antud valdkonnas on kirjandussemiootika määratlemine omaette teadusalana ja suhtes kultuurisemiootikasse. Esimeseks sammuks on teksti ja kultuuri vahelise korrelatsiooni tuvastamine dünaamika mõiste kaudu, toetudes selle mõiste ajaloolisel rekonstrueerimisel vormikoolkonna ja strukturalismi teooriatele (Tõnjanov - funktsioon, Jakobson dominant), aga ka Lotmani (seosed teksti ja kultuuri vahel) ja Bahtini (dialoog) pärandile. Antud teoreetilises kontekstis on tõlgendatud mõisteid 'inklusiivsus/integratsioon', 'distantseerimine' ja 'hierarhiseerimine'. Viidatud traditsioonidel põhineb kolm teksti ja kultuuri dünaamika analüüsitavust tagavat aluskategooriat. Need võimaldavad üldisemal tasandil teksti ja kultuuri paralleelset uurimist: (1) vahendamine - erinevad kultuurikontaktid, erinevatest korrelatsioonidest tulenev semantika, tõlgendamine ja tõlge kui vahendamise viisid, kultuuriteksti saatja ja vastuvõtja vaheline dialoog; (2) transpositsioon - tähendusloome, semantilisi ülekandeid tekitavad nihked, semantilised transformatsioonid, tasandite vaheline dünaamika, "teksti - metateksti" suhted, strukturaalsemantiline kaasamine, integratsioon, hierarhiseerimine, tõlge kui transpositsioon, transmeedialine tõlge jne; (3) ajalis-ruumilisus - protsessilisus, katkestus, lahutamine, staatika ja peatatus vs dünaamika, jutustamine vs kirjeldamine, järkjärguline muutumine vs plahvatus, ajalis-ruumiliste motiivide süsteem, kronotoobid, keskus-perifeeria jne. Pakutud klassifikatsioon võib kaasa aidata "strukturalistliku" ja Peirce'ist lähtuvate teoreetiliste ja metodoloogiliste suundade sünteesile kirjandussemiootikas. See võib anda tõuke kirjandussemiootika distsiplinaarse raami täpsemaks määratlemiseks ja uute analüüsivahendite leidmiseks multimodaalsete ja transmeedialiste nähtuste kirjandussemiootilise eripära selgitamiseks komponentide või kunstilise terviku tasandil. Analoogiliselt võib antud uurimus aidata paremini teadvustada nende lähenemisviiside paratamatut metodoloogilist koosolu, mis (1) seovad mingi kultuurisfääri (kirjanduskultuuri traditsiooni) üldise kultuurisemiootikaga ja (2) toetavad naasmist universaalsete transdistsiplinaarsete mõistete juurest kirjanduskultuuri, kaasates nii kunsti (objekttasand) kui teadusliku tõlgendamise (metatasand) ajaloolised traditsioonid. 